\title{
Teratogenicity of Polybrominated Biphenyls in Rats
}

\author{
Allan R. Beaudoin \\ Department of Anatomy, The University of Michigan, Ann Arbor, Michigan 48109 \\ Received July 28, 1976
}

\begin{abstract}
The teratogenic potential of a mixture of polybrominated biphenyls (PBB) was investigated. Pregnant Wistar albino rats were given single doses of PBB in seasame oil by gavage on one day of pregnancy, from day 6 through 14 (sperm day $=0$ ). The dose ranged from 40 to 800 $\mathrm{mg} / \mathrm{kg}$ maternal body weight. At autopsy (day 20 ) fetuses were recovered and subsequently examined for skeletal and soft-tissue abnormalities. Resorptions followed treatment at all days. No skcletal malformations were seen at any dose level. The majority of soft tissue defects were found following $800 \mathrm{mg} / \mathrm{kg}$ PBB at day 11,12 , or 13 . Only two malformations were produced, cleft palate and diaphragmatic hernia. It is concluded that a single high dose of PBB can be embryolethal and teratogenic to the rat embryo
\end{abstract}

In Michigan, a mixture of polybrominated biphenyls was accidentally mixed with livestock feed. The contaminated feed was consumed by large numbers of farm animals. A toxic syndrome in a dairy herd, attributable to polybrominated biphenyls, has been described (Jackson and Halbert, 1974). There was early anorexia and a dramatic fall in milk production. Necropsy findings suggested the polybrominated biphenyls to be hepatotoxins; liver lesions were the most consistertly reported pathologic change. Embryotoxicity was suspected but not confirmed. Recently, evidence for embryotoxicity in rodents has been presented (Corbett et al., 1975).

Polybrominated biphenyls (PBB) are industrial compounds used mainly as fire retardants. The $\mathrm{PBB}$ mixed with livestock feed was the commercial preparation Firemaster BP-6 (Michigan Chemical Co., St. Louis, Michigan). Fries and Marrow (1975) reported that gas chromatography showed BP-6 contained two major components and at least six minor components. The two major components were identified as a hexabromobiphenyl and a mixture of heptabromobiphenyl and octabromobiphenyls. The minor compounds were not identified.

The present experiment was designed to determine the nature of PBB embryotoxicity in rats.

\section{MATERIALS AND METHODS}

Virgin female Wistar-derived rats from my colony were used. The animals were maintained on Teklad Rat Diet (Teklad Mills, Winfield, Ia.) ad libitum with supplemental feedings of lettuce. Water was available at all times. The day of finding sperm in the vaginal smear was designated day 0 of pregnancy.

The polybrominated biphenyl mixture used in this experiment was the commercial preparation Firemaster BP-6. Solutions of PBB were prepared in sesame oil and administered by gavage at one day of pregnancy, from day 6 to day 14 . Each animal received either $40,200,400$, or $800 \mathrm{mg}$ PBB per kg maternal body weight. Control animals were untreated or received sesame oil by gavage. Since the higher doses of 
PBB caused a sharp drop in food and water consumption, pair-fed controls were used to evaluate a possible nutritional effect.

Pregnancy was terminated at day 20 , resorption sites were counted, and the fetuses recovered, weighed, and fixed. Those fixed in Bouin's fluid were subsequently free-hand sectioned with a razor blade and each slice was examined for malformations. Fetuses fixed in $95 \%$ alcohol were prepared for staining with alizarin red $\mathbf{S}$ for visualization of the skeleton. Samples of maternal liver and fat, as well as whole day 13 and day 14 embryos were analyzed by gas chromatography for PBB concentration.

\section{RESULTS}

The results of administering low doses of PBB to pregnant rats are shown in Table 1. No malformations ascribable to PBB were induced at any treatment day, therefore, only selected days are included in the table. It is noteworthy that two malformed fetuses were found in this experiment, one in the control group and the other in an experimental group. Both fetuses came from mothers treated at day 12 and both had identical malformations; absence of all digits on their paws. It is concluded that this malformation was not due to PBB treatment.

Increasing the dosage of PBB induced malformations (Table 2). Except for treatment with $800 \mathrm{mg} / \mathrm{kg}$ at day $7, \mathrm{PBB}$ caused few maternal deaths. The number of fetal resorptions increased dramatically when the dose was increased from 400 to $800 \mathrm{mg} / \mathrm{kg}$ at day 7 through day 12 . After day 12 the embryolethal effect of PBB declined abruptly. Malformed fetuses were observed in all surviving litters, regardless of the day of treatment. The most susceptible period for the production of abnormalities consisted of days 11,12 , and 13 . At each of these days doubling the dose induced a marked increase in the numbers of fetuses malformed.

Only two malformations were induced by PBB treatment, cleft palate and diaphragmatic hernia (Table 2). Treatment with $800 \mathrm{mg} / \mathrm{kg}$ PBB at day 12 or 13 produced the greatest number of abnormal fetuses. The only other indication of aberrant

TABLE

Embryotoxicity Following Maternal Ingestion of Low Doses of PBB

\begin{tabular}{cccccc}
\hline $\begin{array}{c}\text { Day of } \\
\text { treatment }\end{array}$ & $\begin{array}{c}\text { Dosage } \\
\mathrm{mg} / \mathrm{kg}\end{array}$ & $\begin{array}{c}\text { No. females } \\
\text { surviving/ } \\
\text { no. injected }\end{array}$ & $\begin{array}{c}\text { No. implantation } \\
\text { sites }\end{array}$ & $\begin{array}{c}\% \\
\text { Resorbed }\end{array}$ & $\begin{array}{c}\text { \% Survivors } \\
\text { malformed }\end{array}$ \\
\hline \multirow{2}{*}{6} & 40 & $5 / 5$ & 48 & 6.2 & 0 \\
& 200 & $4 / 4$ & 39 & 41.4 & 0 \\
8 & 40 & $3 / 3$ & 29 & 3.4 & 0 \\
11 & 200 & $4 / 4$ & 47 & 19.1 & 0 \\
& 40 & $5 / 5$ & 59 & 11.8 & 0 \\
12 & 200 & $5 / 5$ & 61 & 9.8 & 0 \\
& 40 & $5 / 5$ & 56 & 5.4 & $1.8^{\prime}$ \\
13 & 200 & $5 / 5$ & 61 & 6.6 & 0 \\
& 40 & $4 / 4$ & 48 & 8.3 & 0 \\
& 200 & $4 / 4$ & 47 & 25.5 & 0 \\
\hline
\end{tabular}

"One embryo lacking digits on all four paws.

${ }^{b}$ One embryo lacking digits on all four paws, treated at day 12. 
TABLE 2

Embryoloxicily Following Maternal Administration of 400 or $800 \mathrm{mg} / \mathrm{kg}$ PBB

\begin{tabular}{|c|c|c|c|c|c|c|c|}
\hline $\begin{array}{l}\text { Day of } \\
\text { treatment }\end{array}$ & $\begin{array}{l}\text { Dosage } \\
\mathrm{mg} / \mathrm{kg}\end{array}$ & $\begin{array}{l}\text { No. females } \\
\text { surviving/ } \\
\text { no. injected }\end{array}$ & $\begin{array}{c}\text { No. implantation } \\
\text { siles }\end{array}$ & $\begin{array}{c}\% \\
\text { Resorbed }\end{array}$ & $\begin{array}{l}\% \text { Survivors } \\
\text { Imalformed }\end{array}$ & $\begin{array}{c}\text { No. with } \\
\text { cleft palate }\end{array}$ & $\begin{array}{c}\text { No. with } \\
\text { Diaphragmatic } \\
\text { hernia }\end{array}$ \\
\hline 6 & $\begin{array}{l}400 \text { or } \\
800\end{array}$ & $12 / 15$ & 98 & 100 & - & $\ldots$ & - \\
\hline \multirow[t]{2}{*}{7} & 400 & $6 / 6$ & 67 & 61.3 & 3.8 & 1 & - \\
\hline & 800 & $1 / 6$ & 7 & 100 & - & - & - \\
\hline \multirow[t]{2}{*}{8} & 400 & $5 / 5$ & 52 & 28.6 & 0 & - & - \\
\hline & 800 & $8 / 10$ & 79 & 72.1 & 13.6 & - & 3 \\
\hline \multirow[t]{2}{*}{9} & 400 & $8 / 8$ & 90 & 28.8 & 3.1 & - & 1 \\
\hline & 800 & $8 / 9$ & 87 & 87.4 & 0 & - & - \\
\hline \multirow[t]{2}{*}{10} & 400 & $6 / 6$ & 63 & 23.8 & 4.1 & - & 2 \\
\hline & 800 & $6 / 6$ & 62 & 59.6 & 12.0 & 1 & 2 \\
\hline \multirow[t]{2}{*}{ II } & 400 & $6 / 7$ & 73 & 6.8 & 11.8 & - & 7 \\
\hline & 800 & $8 / 10$ & 79 & 81.0 & 60.0 & 3 & 7 \\
\hline \multirow[t]{2}{*}{12} & 400 & $11 / 12$ & 122 & 18.0 & 0 & - & - \\
\hline & 800 & $13 / 13$ & 165 & 37.5 & 24.3 & 17 & 12 \\
\hline \multirow[t]{2}{*}{13} & 400 & $7 / 7$ & 107 & 4.6 & 1.9 & 2 & - \\
\hline & 800 & $8 / 8$ & 101 & 8.9 & 24.7 & 21 & 2 \\
\hline \multirow[t]{2}{*}{14} & 400 & $6 / 6$ & 73 & 5.4 & 1.4 & - & I \\
\hline & 800 & $6 / 6$ & 77 & 9.1 & 1.4 & 1 & - \\
\hline $\begin{array}{l}\text { 11. } 12,13 \\
\text { sesame oil }\end{array}$ & & $9 / 9$ & 109 & 10.0 & $1.00^{\prime \prime}$ & - & - \\
\hline
\end{tabular}

${ }^{n}$ One embryo lacking digits on all four paws, treated at day 12.

development were scattered cases of edema, subcutaneous hemorrhage and apparent hydronephrosis, but these conditions may be transitory and, therefore, are not included in the table. There were no skeletal malformations following PBB ingestion at any day of treatment. Alizarin red S preparations of the skeletons of 456 embryos were examined. There was considerable variation in the time of appearance of ossification centers in the sternum and metacarpals in both experimental and control fetuses. This is presumed to reflect individual differences in growth and maturation.

Treatment with low doses of PBB had no effect on fetal weight or placental weight. However, high doses caused significant reductions in both fetal and placental weight. During the most susceptible period (day 11-13) the degree of weight reduction was dependent on the dose administered (Table 3).

Daily weight changes were recorded for all treated animals. During the 24 to 72 hours immediately following PBB administration all treated rats lost weight. The duration of the period of weight loss was dependent upon the dose administered. Rats treated with $40 \mathrm{mg} / \mathrm{kg}$ PBB resumed normal weight gain within 48 hours after treatment. The total weight gained at the end of the experiment was also dose dependent with those rats treated with $800 \mathrm{mg} / \mathrm{kg} \mathrm{PBB}$ exhibiting an overall weight loss (Table 3 ).

Food and water consumption was measured in five animals selected for similar weight. The average daily food intake from day 5 to day 12 of pregnancy was $30.0 \pm$ $4.0 \mathrm{~g}$ per day; water drunk, $49.0 \pm 0.8 \mathrm{ml}$ per day. At day $12,800 \mathrm{mg} / \mathrm{kg}$ PBB was administered. The following two days the animals ate $6.4 \pm 2.6 \mathrm{~g}$ of food and drank $27.7 \pm 8.0 \mathrm{ml}$ of water. Daily food consumption gradually increased during the remainder of pregnancy, but with a great deal of variation among individual rats. The average daily food consumption never did return to pretreatment levels. At the 
TABLE 3

Thf Effects of High Doses of PBB on Maternal Weight Gaix and Fetal and Placental Weight

\begin{tabular}{|c|c|c|c|c|}
\hline Day of treatment & $\begin{array}{c}\text { Dosage } \\
\text { in } \mathrm{mg} / \mathrm{kg}\end{array}$ & $\begin{array}{c}\text { Maternal } \\
\text { weight gain" }\end{array}$ & $\begin{array}{l}\text { Fetal weight }{ }^{b} \\
\text { mean } \pm S D\end{array}$ & $\begin{array}{c}\text { Placental weight } \\
\text { mean } \pm \mathrm{SD}\end{array}$ \\
\hline Untreated control & & $+77 \pm 11.8$ & $3.88 \pm 0.45$ & $0.51 \pm 0.006$ \\
\hline Sesame oil control & & $+88.0 \pm 9.0$ & $4.55 \pm 0.71$ & $0.58 \pm 0.07$ \\
\hline \multirow[t]{2}{*}{11} & 400 & $+20.0 \pm 44.8$ & $3.36 \pm 0.27$ & $0.42 \pm 0.05$ \\
\hline & 800 & $-42.8 \pm 43.2$ & $2.00 \pm 0.60$ & $0.31 \pm 0.10$ \\
\hline \multirow[t]{2}{*}{12} & 400 & $+29.0 \pm 37.2$ & $3.66 \pm 0.60$ & $0.44 \pm 0.04$ \\
\hline & 800 & $-30.6 \pm 33.4$ & $2.66 \pm 0.60$ & $0.35 \pm 0.06$ \\
\hline \multirow[t]{2}{*}{13} & 400 & $+30.8 \pm 23.6$ & $3.64 \pm 0.23$ & $0.45 \pm 0.06$ \\
\hline & 800 & $-23.2 \pm 16.7$ & $2.80 \pm 0.46$ & $0.37 \pm 0.03$ \\
\hline
\end{tabular}

"From day of treatment to day 20. Controls, day 11 to 20

${ }^{b}$ All fetuses from treated mothers weighed significantly less than fetuses from sesame oil control. $P=0.01$ or less.

- All placentae from treated mothers weighed significantly less than placentas from sesame oil controls, $P=0.01$ or less. $P$ values determined by analysis of independent samples $(t$ independent).

last day of the experiment it was $23.6 \pm 6.9 \mathrm{~g}$. Water consumption during this same period was highly variable and exceeded pretreatment levels in most animals. The five treated rats weighed less at day 20 than on the day of treatment. Fetal weights averaged $2.94 \pm 0.35 \mathrm{~g}$ and placental weights $0.38 \pm 0.03 \mathrm{~g}$, both significantly less than fetal and placental weights in sesame oil controls $(4.55 \pm 0.71$ and $0.58 \pm 0.07$ $\mathrm{g}$, respectively).

An additional five pregnant rats were paired by weight with the above five treated animals. Each rat received the same amount of food and water as its pair member from day 5 to day 20 of gestation. At day 12 each received $1.5 \mathrm{ml}$ of sesame oil, but no PBB. The average weight change at day 20 was $+47.5 \pm 3.5 \mathrm{~g}$. The average fetal weight was $3.91 \pm 0.40 \mathrm{~g}$, and the placental weight averaged $0.52 \pm 0.01 \mathrm{~g}$. These weights compare closely with fetal and placental weights of untreated controls ( 3.88 \pm 0.45 and $0.51 \pm 0.06 \mathrm{~g}$, respectively).

Four pregnant rats were treated at day 12 with $800 \mathrm{mg} / \mathrm{kg}$ PBB. At 24 and 48 hours after treatment pooled samples of embryos and maternal liver and fat were analyzed for PBB. Twenty-four hours after PBB administration the maternal liver contained $267 \mathrm{ppm}$ PBB, maternal fat $51 \mathrm{ppm}$, and whole embryos $13 \mathrm{ppm}$. At 48 hours posttreatment maternal liver contained $248 \mathrm{ppm}$, maternal fat $250 \mathrm{ppm}$, and the whole embryo 6 ppm PBB.

\section{DISCUSSION}

There is no doubt that PBB has a toxic effect in animals. In addition to the toxic syndrome described in dairy cattle (Jackson and Halbert, 1974), liver changes have been reported in quail and sheep (Babish et al.. 1975). PBB accumulates in adipose tissue (Fries et al., 1975), appears in the milk of the lactating cow (Fries and Marrow, 1975; Willett and Irving, 1975; Prewitt et al., 1975), and crosses the bovine and mouse placenta (Corbett et al., 1975; Detering et al., 1975). 
The results of this experiment show that single oral doses of PBB at one day of pregnancy during the organogenetic period in the rat can have embryolethal and teratogenic effects. Low doses did not cause frank malformations nor affect fetal or placental weight. This agrees with the observation by Fries and Marrow (1975) of no adverse effects in cows for as long as 1 year after the feeding of low doses of PBB.

Treatment with high doses of PBB is another matter. Following treatment at day 6 there were no surviving embryos. Implantation is in progress at this time and it may be that PBB somehow interferes with this complex process, or simply kills the embryo outright. Following the period of implantation the embryolethal effects of PBB decreased markedly with the $400 \mathrm{mg} / \mathrm{kg}$ dose and remained low for each subsequent day of treatment. However, the $800 \mathrm{mg} / \mathrm{kg}$ dose continued to cause large numbers of embryos to die until at day 13 the embryolethal effect diminished.

PBB caused only cleft palate and diaphragamtic hernia in the rats used in this experiment. At least one malformed fetus was found in litters from each day of treatment, however, the most susceptible days for the production of abnormalities were days 11,12 , and 13 . Only following treatment at day 12 were there many fetuses exhibiting both defects. No significance was given the observation that a delay in the appearance of sternal and metatarsal ossification centers often followed PBB treatment. There was also considerable variation among control embryos in the appearance of these ossification centers. The delay in the experimental rats probably only reflects the delayed growth of the fetus, as indicated by lower fetal weights. Similar observations have been made by other investigators (Kimmel and Wilson. 1973).

The anorexia and weight loss seen in the rats following high doses of PBB administration agrees with what has been reported in dairy cattle (Jackson and Halbert, 1974). The fact that pair-fed controls had similar numbers of fetuses with comparable weight to sesame-oil-fed controls indicated that inanition, while reducing maternal weight gain, was not the cause of resorptions or malformations in the PBB treated rats. It is, however, most likely responsible for the marked reduction in fetal weight.

The results of this experiment have shown that single high doses of PBB can be embryolethal and teratogenic to the rat embryo. Low doses had no observable detrimental effects on pregnancy. PBB was found in maternal liver and fat, as well as in the whole embryo. At this writing no human malformations, nor fetal deaths, have been attributed to maternal contamination with $\mathrm{PBB}$.

\section{ACKNOWLEDGMENTS}

Supported by NIH Research Grant HD 00400. The determination of tissue levels of PBB was provided by Dr. T. H. Corbett, The Research Service, U.S.V.A. Hospital Ann Arbor, Michigan.

\section{REFERENCES}

Babish, J. G., Guntemann. W. H., Lisk, D. J., and Stoewsand, G. S. (1975). Liver changes and tissue residues of animals fed hexabromobiphenyl. Fed. Proc. 34, 157.

Corbett, T. H., Beaudoin. A. R., Cornell, R. G., Anver, M. R., Schumacher. R., Endres, J., and Szwabowska, M. (1975). Toxicity of polybrominated biphenyls (Firemaster BP-6) in rodents. Environ. Res. 10, 390-396.

Detering, C. N.. Prewitt, L. R., Cook, R. M. and Fries, G. F. (1975). Placental transfer of polybrominated hiphenyl by Holstein cows. J. Dairy Sci. 58, 764. 
Fries. G. F., and Marrow, G. S. (1975). Excretion of polybrominated biphenyls into the milk of cows. J. Dairy Sci. 58, 947-951.

Fries, G. F., Marrow, G. S., Detering, C. N., Prewitt, L. R., and Cook, R. M. (1975). Distribution of polyprominated biphenyl residues in tissues of dairy cattle. J. Dairy Sci. 58, 764.

Jackson, T. F., and Halbert, F. L. (1974). A toxic syndrome associated with the fecding of polybrominated biphenyl contaminated protein concentrate to dairy cattle. J. V. M. A. 165, 437-439.

Kimmel, C. A., and Wilson, J. G. (1973). Skeletal deviations in rats: Malformations or variations? Teratology 8, 309-316

Prewitt, L. R., Cook, R. M., and Fries, G. F. (1975). Field observations of Michigan dairy cattle contaminated with polybrominated biphenyl. J. Dairy Sci. 58, 763.

Willett. L. B., and Irving, H. A. (1975). Distribution and clearance of polybrominated biphenyls by cows. J. Dairy Sci. 58, 764. 